\title{
Gene Expression and Secretion of Atrial Natriuretic Peptide by Murine Macrophages
}

\author{
Angelika M. Vollmar and Rüdiger Schulz \\ Institute of Pharmacology, Toxicology and Pharmacy, University of Munich, Königinstr. 16, D-80539 München, Germany
}

\begin{abstract}
An increased expression of atrial natriuretic peptide (ANP) has been reported in activated macrophages of the acutely involuted rat thymus. We communicate here that ANP may refiect a common constituent of macrophages, as mRNA coding for ANP is present in peritoneal- as well as in bone marrow-derived macrophages (PM, BMM). Furthermore, both types of macrophages synthesize and release ANP which was found to mainly represent the biologically active fragment ANP99-126.

ANP expression in macrophages is regulated by compounds affecting the activity of these immune cells. For example, incubation of PM or BMM in vitro with LPS and zymosan, respectively, increased ANP-mRNA up to sixfold as determined by competitive PCR quantification. Exposure of macrophages to dexamethasone (Dex, $10^{-7} \mathrm{M}$ ) elicits moderate effects (1.4-fold), while PMA $\left(10^{-7} \mathrm{M}\right)$ failed to affect its abundance. These findings are complemented by data regarding ANP synthesis and secretion. Incubation of macrophages with LPS, Dex or a combination of both results in an up to 3.5-fold increase of intracellular ANP99-126 (basal $10 \mathrm{fmol} / \mathrm{mg}$ protein), and an up to 6.6-fold increase of its secretion (basal $40 \mathrm{fmol} / \mathrm{mg}$ protein, $24 \mathrm{~h}$ ). Since macrophages synthesize and release ANP, the peptide may be involved in the complex mechanisms of host defense, a major function of these immune cells. (J. Clin. Invest. 1994. 94:539-545.) Key words: polymerase chain reaction • immune system • flow cytometry • HPLC • immunocytochemistry
\end{abstract}

\section{Introduction}

It is commonly accepted that atrial natriuretic peptide (ANP) ${ }^{1}$ plays an important role in cardiovascular physiology (for review see reference 1). However, there is increasing evidence that its spectrum of biological activity may exceed the latter $(2,3)$.

Address correspondence to Dr. Angelika M. Vollmar, Institut für Pharmakologie, Toxikologie und Pharmazie, Königinstr. 16, D-80539 München, Germany.

Received for publication 28 September 1993 and in revised form 7 March 1994.

1. Abbreviations used in this paper: ANP, atrial natriuretic peptide; $\mathrm{BM}$, bone marrow; BMM, bone marrow-derived macrophages; $\mathrm{CN}$, control cells; Dex, dexamethasone; DHR, dihydrorhodamin-123; gDNA, genomic DNA; PM, peritoneal macrophages.

J. Clin. Invest.

(C) The American Society for Clinical Investigation, Inc.

0021-9738/94/08/0539/07 \$2.00

Volume 94, August 1994, 539-545
For instance, ANP has been described to affect the reproductive system (4), to elicit antimitogenic (5) and to possess cytoprotective effects (6). We previously reported that this peptide is present in various organs of the immune system $(3,7-9)$ and more recently, this notion has been further strengthened by the finding that ANP expression is regulated in immune organs. In fact, ANP-mRNA of the thymus is strongly elevated upon treatment of rats either with dexamethasone or exposure to $\mathrm{x}$ rays $(10,11)$. Detailed studies revealed that thymic ANP is localized in macrophages $(11,12)$, a finding recently confirmed by others (13). The increased ANP production of the acutely involuted thymus was suggested to be linked to the activation of thymic macrophages caused by the vast lysis of thymocytes $(11,12)$.

The studies conducted so far have left unanswered, whether the augmented ANP expression constitutes a general phenomenon of activated macrophages or reflects a specific response of thymic macrophages to acute involution of the organ. Moreover, no information is available as to whether ANP expression in macrophages is accompanied by release of this peptide.

It was the aim of the present study to examine as to whether macrophages other than those in the thymus express and secrete ANP. For this purpose, cell cultures of bone marrow-derived macrophages as well as peritoneal macrophages were investigated. It was further intended to study whether activation of macrophages in culture upon exposure to various stimuli leads to an increased ANP production and secretion. These experiments shall evaluate as to whether ANP represent a general constituent of macrophages and whether the peptide underlies specific regulatory mechanisms.

\section{Methods}

\section{Cells}

Bone marrow-derived macrophages (BMM). Bone marrow cells were obtained by flushing (RPMI medium, GIBCO, UK) femurs of mice (Balb/c, female, $20 \mathrm{~g})$ and seeded into cell culture flasks $\left(2 \times 10^{5}\right.$ cells/ $\mathrm{ml}, 175-\mathrm{cm}^{2}$ flasks; Greiner, Frickenhausen, FRG). Culture medium was composed of RPMI medium, containing $20 \%$ ( vol/vol) L-cell conditioned medium (LCM) as a source of the macrophage growth factor (14), 10\% FCS (GIBCO) and penicillin (100 U/ml)/streptomycine $(100 \mu \mathrm{g} / \mathrm{ml})$. After $24 \mathrm{~h}$, non-adherent BM were transferred to new flasks and grown in the above mentioned medium for 5-6 d $\left(5 \% \mathrm{CO}_{2}\right.$, $37^{\circ} \mathrm{C}$ ). BMM were made quiescent by removing LCM and FCS at least $12 \mathrm{~h}$ before adding various chemical stimuli, that is $1 \mu \mathrm{g} / \mathrm{ml}$ LPS ( $E$. coli, serotype 055; Sigma, FRG), PMA, $10^{-7} \mathrm{M}$ (Sigma), zymosan, $10^{6}$ cells $/ \mathrm{ml}$ (Sigma), and Dex, $10^{-7} \mathrm{M}$ (Fortecortin ${ }^{8}$, Bayer, FRG), respectively.

Peritoneal macrophages (PM). Mice (Balb/c, female, 20-30 g) were injected (i.p.) with $1 \mathrm{ml}$ thioglycollate broth (4\%, GIBCO) 3-4 $\mathrm{d}$ before harvesting cells by washing the peritoneum with ice-cold RPMI medium, containing $10 \%$ FCS. When necessary erythrocytes were lysed by exposure to $\mathrm{NH}_{4} \mathrm{Cl}$ buffer $\left(150 \mathrm{mM} \mathrm{NH}_{4} \mathrm{Cl}, 20 \mathrm{mM} \mathrm{KHCO}_{3}, 0.1\right.$ $\mathrm{mM}$ EDTA) for $3 \mathrm{~min}, 37^{\circ} \mathrm{C}$. Macrophages were obtained by plating the peritoneal cells (flasks $175 \mathrm{~cm}^{2}, 10^{5}$ cells $/ \mathrm{ml}, 37^{\circ} \mathrm{C}, 5 \% \mathrm{CO}_{2}$ ) in 
RPMI medium (10\% FCS). After 2 h, non-adherent cells were sucked off and fresh medium, lacking FCS, was added for at least $6 \mathrm{~h}$ before exposure of the cells to various reagents (see above).

BMM and PM were assessed to be pure ( $>85 \%$ ) by FACS analysis (FACscan; Becton Dickenson, Mountain View, CA), using a FITClabeled antiserum against the macrophage antigen F40/80 (15) (Serotec LTD, Wiesbaden, FRG), as well as by staining for unspecific esterase activity (NASAE) (16). Functional activity of the macrophages was confirmed by demonstration of phagocytosis (fluorescent latex particles; Polysciences, Heidelberg, FRG) according to Parod and Brain (17) as well as of respiratory burst activity by use of dihydrorhodamine123 (18).

\section{Chromatographic analysis of extracts of cells and medium}

Cells. Cells were washed twice with PBS $\left(4^{\circ} \mathrm{C}\right)$ before $1 \mathrm{M}$ acetic acid $\left(95^{\circ} \mathrm{C}\right)$ was added to the monolayer, followed by boiling for $1 \mathrm{~min}$ in the microwave. Cell debris was harvested (rubber policeman) in acetic acid and centrifuged $(20,000 \mathrm{~g}, 20 \mathrm{~min})$. Clear supernatant was pumped ( $0.5 \mathrm{ml} / \mathrm{min}$ ) onto Sep Pak C 18 cartridges (Waters, Milford, UK) and washed with $0.1 \%$ trifluoroacetic acid (TFA). The retained material was eluted with $60 \%$ acetonitrile/ $0.1 \%$ TFA. After lyophilization, cell extracts were analyzed by RP-HPLC ( $\mu$ Bondapak, $20-50 \%$ acetonitrile in TFA, flow rate $1 \mathrm{ml} / \mathrm{min}$ ) and RIA as previously described (7-9).

The concentration of ANP-IR in FCS has been determined after extraction ( $1 \mathrm{ml}$ ) by Sep Pak C18 cartridges using RIA (see above) and amounted to $34.0 \pm 4.3 \mathrm{fmol} / \mathrm{ml}$. For examination of a possible uptake of ANP originating from FCS by macrophages, cells were incubated with ${ }^{125} \mathrm{I}$-ANP99-126 $\left(60,000 \mathrm{cpm} / 10^{7}\right.$ cells, specific activity $2,000 \mathrm{Ci} / \mathrm{mmol}$, Amersham, FRG) for various periods of time $(2,6$, $12,24,48,72 \mathrm{~h}$ ). At each time point medium of cells was removed, the cells were washed and solubilized with $1 \mathrm{M} \mathrm{NaOH}$. Radioactivity of medium and solubilized cells was counted ( $\gamma$-counter, Pharmacia/ LKB, Freiburg, FRG). Time-dependent degradation of labelled ANP was analyzed by HPLC.

Medium. For analysis of secreted IR-ANP, supernatant of cell cultures were applied onto an ANP-immunoaffinity column $(1 \mathrm{ml} / \mathrm{min})$. The gel matrix consisted of protein A purified anti-rat ANP99-126 immunoglobulins of antiserum "Loisl" (7) bound to activated NHSSepharose gel (HiTrap $1 \mathrm{ml}$; Pharmacia). The antiserum recognizes the prohormone ANP1-126 to $\sim 50 \%$. Bound ANP-immunoreactive material was eluted with $0.1 \mathrm{M}$ glycine buffer, $\mathrm{pH} 2$, and desalted by adsorption on Sep Pak $\mathrm{C}_{18}$ cartridges. ANP was eluted with $60 \%$ acetonitrile in $0.1 \%$ TFA. Lyophilized extracts were subjected to HPLC analysis and RIA as described above.

Quantification of intra- and extracellular ANP-IR relates to three independent cell preparations both for stimulated and unstimulated cells. Values are given as means \pm SD and differences in ANP levels were evaluated by Student's $t$ test $(P<0.05$ significant differences).

Recovery. For determination of extraction efficiency ${ }^{125} \mathrm{I}-\mathrm{ANP}$ $(30,000 \mathrm{cpm}$, specific activity $2,000 \mathrm{Ci} / \mathrm{mmol})$ was added as internal standard to cells as well as to supernatant prior to its extraction and subsequent chromatographic analysis.

\section{mRNA analysis}

Extraction. Total cellular RNA was extracted using the guanidiniumthiocyanat/cesiumchloride method (19). mRNA was enriched by oligo dT-adsorption (Polytract; Promega, Madison, WI).

Northern Blot analysis. The method was performed as described (9). Briefly, $20 \mu \mathrm{g}$ total mRNA from treated and untreated cells was separated by agarose gel electrophoresis, blotted on Nylon membranes (Hybond N; Amersham, Braunschweig, FRG) and hybridized with a 585-bp comprising ANP cRNA (20) (kindly provided by Dr. Lang, Marburg, FRG). Blots were exposed for $6 \mathrm{~d}$ to $\mathrm{x}$-ray films $\left(-70^{\circ} \mathrm{C}\right)$.

$P C R$ analysis. mRNA content of each sample has been evaluated by dot-blot hybridization to an end-labeled $p(d T)_{12-18}$ as described (21). cDNA synthesis was performed as described $(21,22)$ except for the fact that the efficiency of reverse transcription was evaluated by adding $\left(\alpha-{ }^{32} \mathrm{P}\right) \mathrm{dCTP}$ ( $400 \mathrm{Ci} / \mathrm{mmol}$; Hartmann Analytic, Braunschweig, FRG) to an aliquot of the reaction mix. Incorporated radioactivity was determined after separation of free-labeled dCTP using glass fiber filters (GF/B; Whatman, Maidstone, England) (23). cDNA synthesis efficiency varied between 40 and $80 \%$, and cDNA content has been equalized prior PCR analysis.

PCR has been performed as described $(21,22)$. Briefly, sense primer (5'-CAGCATGGGCTCCTTCTCCA-3') and antisense primer (5'GTCAATCCTACCCCCGAAGCAGCT-3') corresponding to the first and second exon of the mouse ANP gene (20) as well as Taq DNA polymerase (2.5 U/tube; Promega, Heidelberg, FRG) were used. 37 cycles were performed. Experiments assessing conditions for linear amplification, i.e., variation of initial amount of cDNA and genomic DNA (gDNA) as well as of number of cycles, were conducted. Identical efficiencies of gDNA and various cDNA amplifications were demonstrated by parallelity of kinetic curves ( $20-45$ cycles) of amplification.

Quantitative PCR. For relative quantification of PCR products the competitive polymerase chain reaction has been used as described earlier (24). A constant amount of cDNA (30 $\mathrm{ng}$ ) and serial dilutions of competitor DNA (mouse gDNA 25-200 ng) were amplified in 37 cycles as described earlier (22), except for the fact that each reaction mixture included $\left(\alpha-{ }^{32} \mathrm{P}\right)$ dCTP $(1 \mu \mathrm{Ci} ; 3,000 \mathrm{Ci} / \mathrm{mmol})$. Aliquots $(6 \mu \mathrm{l})$ of PCR products were analyzed (gDNA 555 bp; cDNA 451 bp) by acrylamide gel electrophoresis (6\% acrylamide) with silver nitrate staining (23) followed by exposure to an $\mathrm{x}$-ray film $\left(-70^{\circ} \mathrm{C}, 12 \mathrm{~h}\right)$. Thereafter, the specific bands were cut into vials containing scintillation liquid, and the radioactivity counted ( $\beta$-counter; Beckman Instruments, FRG). In all sets of experiments the presence of possible contaminants was checked by control reactions in which either cDNA was omitted or mRNA (30 ng) instead of cDNA was added. As positive control, cDNA (5 ng) from mouse ventricles was included, of which PCR amplification product has been sequenced before (22). PCR amplification of samples has been performed in triplicates and the experiments repeated three times with independent cell preparations.

\section{Immunocytochemistry}

BMM were grown (not reaching confluence) on glass slides in cell culture dishes (RPMI medium 10\% FCS, 20\% LCM). PM (thioglycollate elicited) were seeded for $2 \mathrm{~h}\left(37^{\circ} \mathrm{C}, 5 \% \mathrm{CO}_{2}\right)$ on glass slides. Cells were fixed with Zamboni's fluid $(25)\left(10 \mathrm{~min}, 25^{\circ} \mathrm{C}\right)$, washed with PBS and subsequently treated with $0.0025 \%$ digitonin (Sigma) in PBS $\left(10 \mathrm{~min}, 25^{\circ} \mathrm{C}\right)$. To block binding of antibody to $\mathrm{Fc}$ receptor sites on the macrophages cells were incubated with normal mouse serum (1:10 diluted, $20 \mathrm{~min}, 25^{\circ} \mathrm{C}$ ), followed by incubation with diluted normal goat serum (ABC Vectastain kit; Vector Laboratories, Inc., Burlingame, CA) $\left(10 \mathrm{~min}, 25^{\circ} \mathrm{C}\right)$. Two different antisera ("Loisl" and "Toni," 1:800 and 1:1600 dilutions in PBS) (7) were employed as primary antibody $\left(2 \mathrm{~h}, 25^{\circ} \mathrm{C}\right)$. After incubation with biotinylated goat anti-rabbit IgG $\left(1 \mathrm{~h}, 25^{\circ} \mathrm{C}\right)$, the ANP-immunoreaction was made visible by incubation with diaminobenzidine tetrahydrochloride $(1 \mathrm{mg} / \mathrm{ml})$ and hydrogen peroxide $(0.01 \%)\left(90 \mathrm{~s}, 25^{\circ} \mathrm{C}\right)$. Cells were counterstained with $0.01 \%$ hematoxylin for $5 \mathrm{~s}$. Controls included omission of the primary antisera, use of normal rabbit serum (1:800 dilution) and anti-ANP antisera preabsorbed with ANP99-126 $\left(5 \mu \mathrm{g} / 100 \mu \mathrm{l}, 24 \mathrm{~h}, 4^{\circ} \mathrm{C}\right)$.

\section{Cortisol-like material in the culture medium}

Cortisol-like immunoreactivity in RPMI medium containing LCM and FCS has been determined by ELISA (26). For some experiments concentration of cortisol-IR in the culture medium has been diminished by adsorption to charcoal (Norit; Merck, Darmstadt, FRG; column $2 \times 25$ $\mathrm{cm}$, flow $1 \mathrm{ml} / \mathrm{min}$ ).

\section{Results}

\section{Characterization of cells}

Unless noted differently, cells were cultured in medium containing $10^{-9} \mathrm{M}$ cortisol-like material (ELISA) originating from FCS. To prove the identity and purity of cultured cells, PM and 

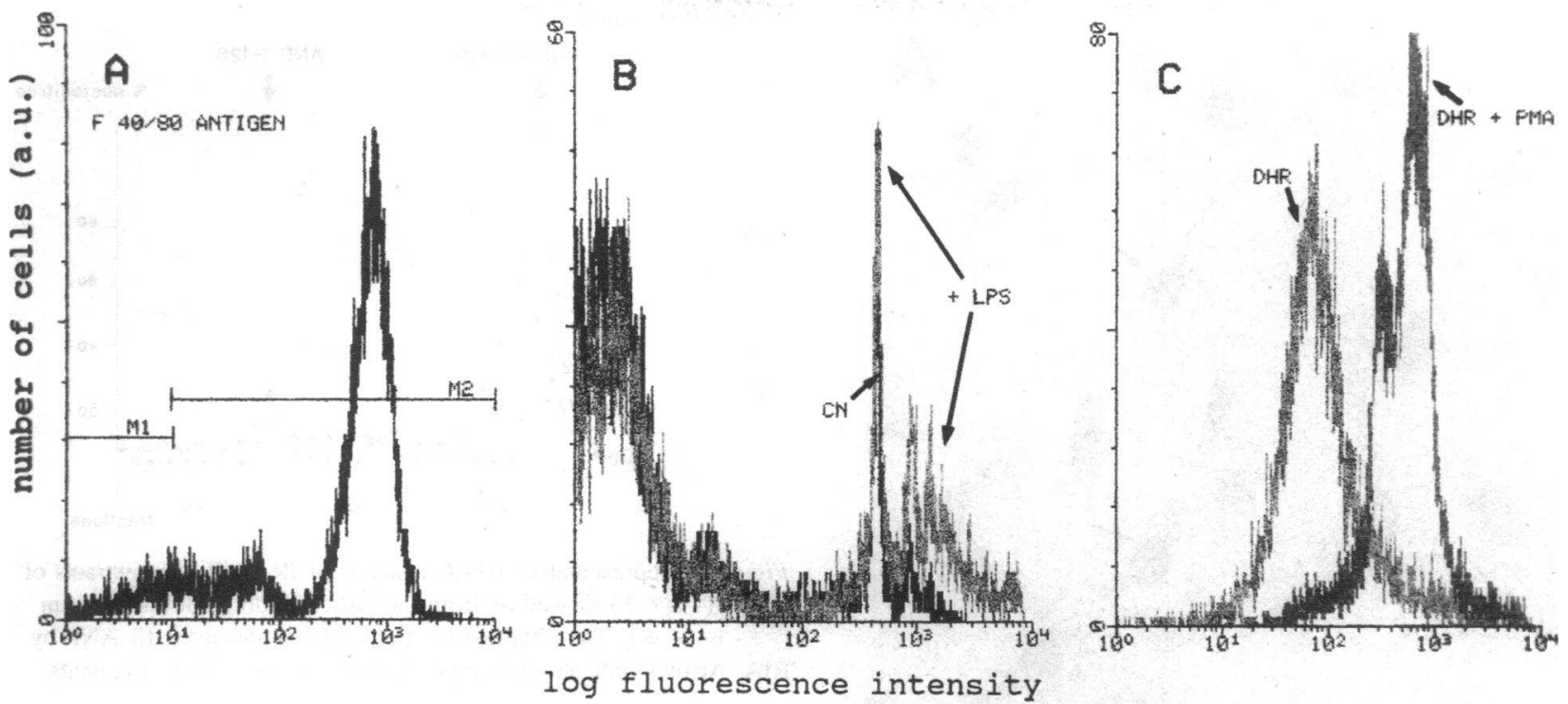

Figure 1. (A) Analysis of peritoneal macrophages by flow cytometry using an FITC-labeled antibody against macrophage antigen F40/80. A histogram of fluorescence (FL1) versus counts for cells stained with FITC-anti-F40/80 is shown. Marker set around stained (M2) and unstained cells $(M 1)$ allows the number of positive macrophages to be counted. $(B)$ Demonstration of phagocytosis by FACS. BMM-derived macrophages $\left(10^{6} / \mathrm{ml}\right)$ were preincubated with LPS $(1 \mu \mathrm{g} / \mathrm{ml}, 18 \mathrm{~h})$ and exposed to fluorescent latex particles $\left(10^{7} / \mathrm{ml}\right)$ for $2 \mathrm{~h}$. Control cells $(C N)$ were only incubated with latex particles. Degree of phagocytosis is demonstrated by the intensity of cellular fluorescence (abscissa) blotted against amount of cells. $(C)$ Measurement of the respiratory burst activity (fluorescence intensity) of peritoneal macrophages incubated with dihydrorhodamin-123 $(\mathrm{DHR})(1 \mu \mathrm{M})$ alone or with DHR and PMA $\left(10^{-7} \mathrm{M}\right)$ for $10 \mathrm{~min}$. All histograms were obtained from measurements on a FACScan flow cytometer using Lysis II FACScan software.

BMM were examined for the presence of macrophage-specific antigen F $40 / 80$ by FACS analysis (Fig. 1) as well as for unspecific esterase activity (NASAE) (data not shown). Referring to these criteria both cell types were shown to be $\sim 90 \%$ pure. Furthermore, functional activities of the cells have been proven by their response to LPS ( $1 \mu \mathrm{g} / \mathrm{ml}, 24 \mathrm{~h})$, as it stimulates phagocytosis of opsonized, fluorescent latex particles. Furthermore, exposure to PMA $\left(10^{-7} \mathrm{M}\right)$ as well as to zymosan $\left(10^{6}\right.$ cells $/ \mathrm{ml}$ ) elicits an increase of respiratory burst activity (Fig. 1 ). Both functional parameters were examined by means of flow cytometry as described $(17,18)$.

\section{ANP-mRNA expression and production in mouse peritoneal and bone marrow derived macrophages}

Expression of ANP-mRNA in PM as well as BMM has been demonstrated by Northern Blot analysis (Fig. 2). Hybridization of purified mRNA (20-50 $\mu \mathrm{g}$ per lane) with an radiolabelled ANP cRNA (20) yield a distinct hybridization band of 980 nucleotides (nt) which comigrates with control mRNA extracted from mouse atria.

The production of ANP by PM and BMM was revealed by

Figure 2. Representative Northern blot hybridization of mRNA extracted from PM (lane 2, $20 \mu \mathrm{g}$; lane $3,30 \mu \mathrm{g})$ and $\mathrm{BMM}$ (lane 4, $30 \mu \mathrm{g}$; lane 5, 50 $\mu \mathrm{g}$ ). The transcript ( 950

$$
\begin{array}{llllllll}
1 & 2 & 3 & 4 & 5 & 6 & \begin{array}{l}
\mu \mathrm{g}) \text {. The transcript } \\
\mathrm{nt}) \text { comigrated with }
\end{array}
\end{array}
$$

ANP-mRNA from mouse atria (lane $1,0.01 \mu \mathrm{g}$ total RNA; lane 6, 0.03 $\mu \mathrm{g}$ total RNA). $n t$, nucleotides. immunocytochemistry. By means of ANP antisera, recognizing different epitopes of ANP (7), both types of macrophages show intense cytoplasmatic ANP-immunostaining. A representative experiment employing BMM is shown in Fig. 3. Immunostaining was absent using either normal rabbit serum or antisera that has been preabsorbed with synthetic ANP99-126 (Fig. 3).

ANP-IR in macrophages was further confirmed and characterized by HPLC-analysis of cell extracts and RIA. As shown in Fig. 4, immunoreactivity of BMM cultured under standard conditions ( $10^{-9} \mathrm{M}$ cortisol-IR), elutes as a major peak corresponding to ANP99-126. In addition, small amounts of ANPIR referring to the precursor form ANP1-126 were found (ratio ANP1-126/ANP99-126 = 1:5). Extract of cells grown in medium with reduced cortisol-IR $\left(<10^{-11} \mathrm{M}\right)$ showed a reverse pattern of ANP-immunoreactivity, i.e., ANP 1-126 was the predominant form of ANP-IR (ratio ANP1-126/ANP99-126 $=2.5: 1$ ) (data not shown).

A possible uptake of ANP99-126, originating from FCS, by macrophages, during culturing is negligible having shown that $<2 \%$ of labeled ANP added to the culture medium for any period of time tested $(2,6,12,24,48,76 \mathrm{~h})$ was found to be associated with the cells. Moreover, as demonstrated by HPLC analysis of labeled ANP present in the supernatant, the peptide is degraded ( $50 \%$ after $12 \mathrm{~h}$ ) under the culture conditions used (10\% FCS) (data not shown).

To find out whether macrophages are able to secrete ANP, culture medium lacking FCS has been examined for the presence of ANP-IR. Apparently, enrichment of ANP by means of immunoaffinity chromatography of FCS-free medium before HPLC/RIA analysis was mandatory to obtain reproducible results. Direct measurement of aliquots of acidic cell or medium extracts by RIA did not yield reproducible results nor did serial 

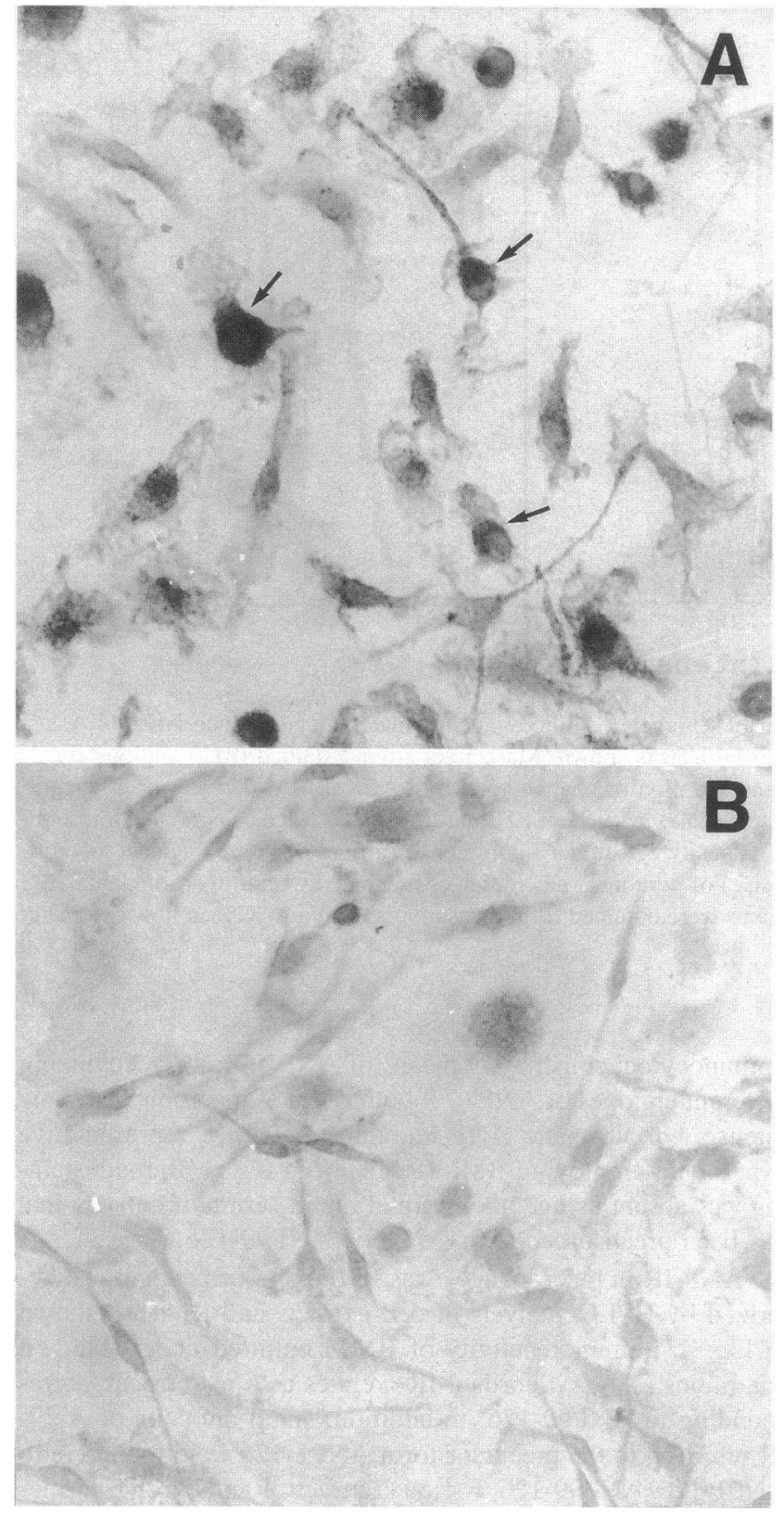

Figure 3. Immunohistochemistry of BMM. ANP-immunoreactivity has been detected by brown reaction products in the cytoplasma (arrows) after incubation with ANP-antiserum "Loisl"' $(1: 1600)(A)$. Cells incubated with ANP-antiserum preadsorbed with ANP99-126 only show weak background staining $(B)$. In both cases cells were weakly counterstained with hematoxylin.

dilution of samples display parallelity to RIA standard curve (data not shown). Comparable binding capacity of ANP-immunoaffinity columns as well as recovery of bound ANP material ( $\sim 54 \%$ of loaded ANP) has been determined by adding labeled ANP as internal standard.

Secretion of ANP-IR was indeed demonstrated as the medium contained the ANP99-126 fragment (HPLC analysis, Fig. 4).

PM and BMM contain 8 and 10 ANP-IR fmol/mg protein and spontaneously secrete (24-h period) $40 \mathrm{fmol} / \mathrm{mg}$ cell pro-

\section{IR-ANP (fmol/tube)}

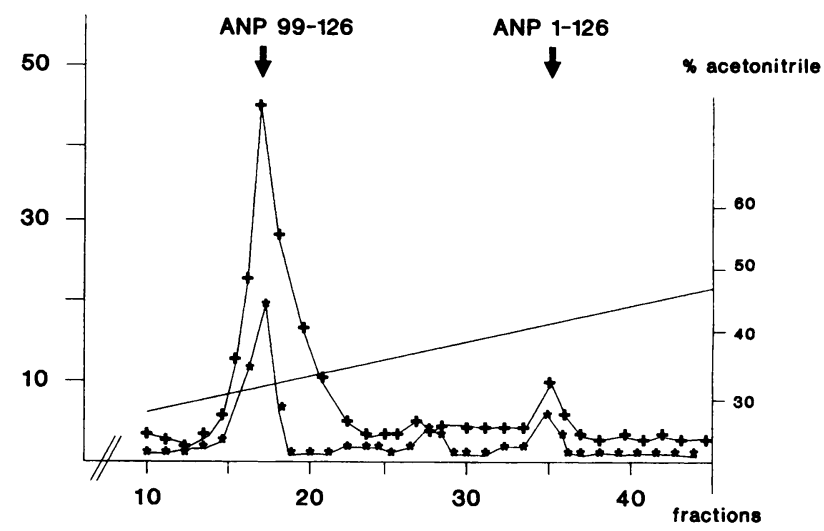

Figure 4. Representative HPLC-analysis of IR-ANP from extracts of BMM $\left(-_{-} *_{-} *^{*}\right)$ as well as from the corresponding culture medium $(-+-+-+-+)$. The obtained fractions were assayed for IR-ANP by RIA. Arrows indicate elution position of synthetic ANP fragments.

tein, respectively. Values are corrected for a loss of IR during analysis of cells (64\%) and supernatant (72\%).

\section{Effects of stimulation of macrophages on ANP-mRNA and IR-ANP production}

Competitive PCR analysis. Due to the low abundance of ANPmRNA, the PCR technique has been used to examine the effect of various stimuli on ANP-mRNA expression of macrophages. For the purpose of quantification special consideration has been given to the following points. (a) The efficiency of the reverse transcription, which may considerably vary (between 40 and $80 \%$ ), has been determined by incorporation of radioactivelabeled dCTP as described in Methods. ( $b$ ) PCR reactions have been assured to remain in the exponential phase determining both the appropriate initial amount of template used as well as the number of cycles employed. Accordingly, $30 \mathrm{ng}$ of cDNA were employed in combination with $25-200$ ng gDNA and 37 cycles of amplification were conducted. (c) Mouse gDNA served as internal standard DNA for the competitive PCR procedure (21). Thereby, equal efficiencies of amplification of the ANP specific sequences of gDNA and cDNA, respectively, have been proven by parallel kinetic curves ( $20-45$ cycles ) of amplification.

Fig. 5 shows a representative experiment performed with cDNA (30 ng) from unstimulated and stimulated (zymosan, $10^{6}$ cells $/ \mathrm{ml}, 18 \mathrm{~h}$ ) PM with decreasing amounts of standard DNA (gDNA, 200-25 ng) added. As the gDNA decreases, the signal of the amplification product ( $555 \mathrm{bp}$ ) became less intense, and intensity of the target cDNA (451 bp) increases. Bands were cut, quantified by their amounts of radioactivity and the PCR product ratio (gDNA/cDNA) was plotted as a function of the initial amount of gDNA (Fig. 6).

Based on the equivalence region, where the PCR product ratio was around 1 , a shift towards right of the curves obtained from cells stimulated with LPS ( $1 \mu \mathrm{g} / \mathrm{ml}, 18 \mathrm{~h}$ ) and zymosan $\left(5 \times 10^{6}\right.$ cells $\left./ \mathrm{ml}, 4 \mathrm{~h}\right)$ indicates increased amounts of PCR products (Fig. 6). Dex $\left(10^{-7} \mathrm{M}\right)$ and PMA $\left(10^{-7} \mathrm{M}\right)$ display either moderate or no stimulatory effect on ANP-mRNA. Fig. 7 summarizes the effect of the various stimuli on ANP-mRNA of PM expressed as percentage of untreated cells $(100 \pm 23$ SD\%) (LPS: $290 \pm 70 \%$, LPS + Dex: $410 \pm 74 \%$, zymosan: 


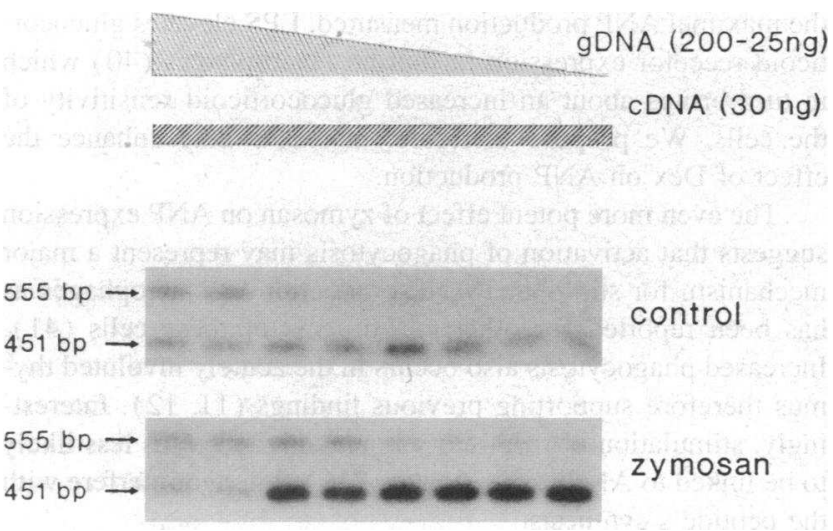

Figure 5. Representative competitive PCR of cDNA (30 ng each) of untreated PM and PM incubated with zymosan $\left(10^{6} \mathrm{cell} / \mathrm{ml}, 18 \mathrm{~h}\right) \mathrm{co}-$ amplified with decreasing amounts of gDNA (200-25 ng). Amplification and separation by PAGE (gDNA 555 bp; cDNA 451 bp) were carried out as described in Methods. PAGE gels were exposed to x-ray films for $18 \mathrm{~h}$ at $-70^{\circ} \mathrm{C}$.

$590 \pm 90 \%$, Dex: $120 \pm 30 \%$, PMA: no increase). Stimulation of BMM showed similar effects on concentration of ANPmRNA (LPS: $240 \pm 30 \%$, LPS + Dex: $360 \pm 90 \%$, zymosan: $510 \pm 100 \%$, Dex: $120 \pm 10 \%$, PMA: no increase).

HPLC/RIA analysis. The content of ANP-IR in BMM (11.4 $\pm 5.8 \mathrm{fmol} / \mathrm{mg}$ protein) was increased by exposure to LPS $(1 \mu \mathrm{g} / \mathrm{ml}, 24 \mathrm{~h}), \mathrm{DEX}\left(10^{-7} \mathrm{M}, 24 \mathrm{~h}\right)$ as well as by a combination of both compounds (i.e., LPS: $39.9 \pm 9.2 ; P<0.05$, Dex: $17.4 \pm 5.2 \mathrm{NS}$; LPS/DEX: $23.4 \pm 2.8 \mathrm{fmol} / \mathrm{mg}$ protein, $P<0.05$ ) (Fig. 8). Total ANP-IR consists of ANP99-126, accompanied by small amounts of ANP1-126. The response of cellular ANPIR upon stimulation of PM (basal 7.9 $\pm 4.2 \mathrm{fmol} / \mathrm{mg}$ protein) was found to be in the same range (LPS: $24.2 \pm 5.1 P<0.05$;

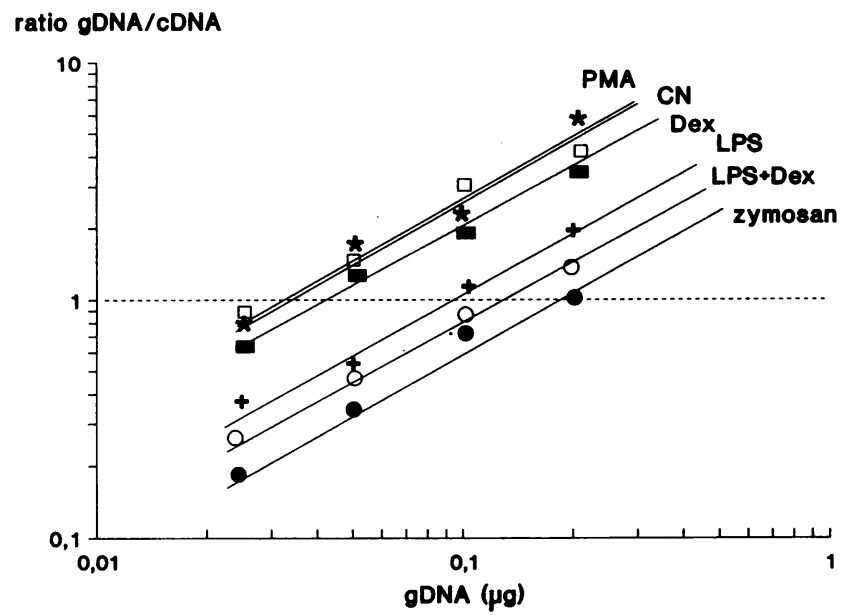

Figure 6. Titration curves of cDNA from untreated $(\square)$ cells and cells incubated with LPS (+), Dex ( $\bullet)$, LPS + Dex (O), zymosan $(\bullet)$ and PMA $\left({ }^{*}\right)$ as described in Methods. Curves were obtained by excising the bands of PAGE gels stained with silver nitrate (see Fig. 5) and determining the radioactivity recovered from the specific PCR products. Background values were subtracted. The ration of gDNA/cDNA related radioactivity is plotted on a log-log scale against the amount of gDNA. Values represent the means of three independent experiments with triplicate samples.

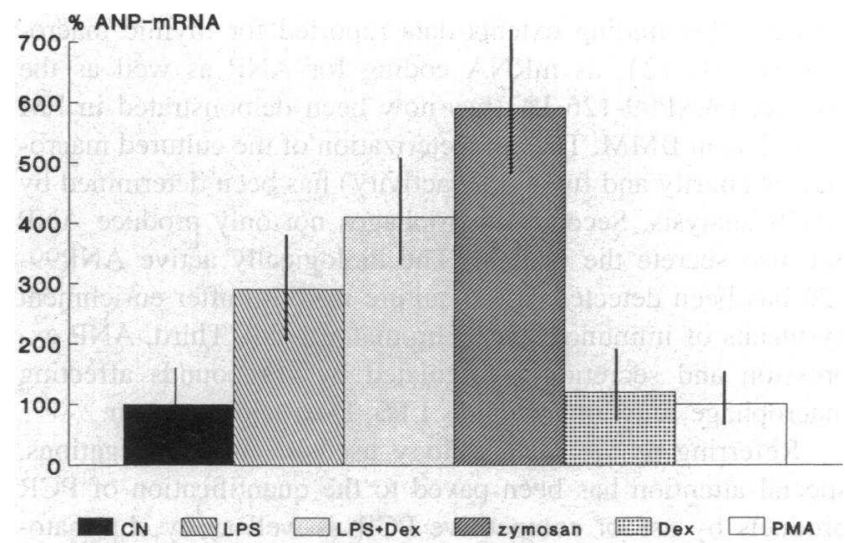

Figure 7. Relative ANP-mRNA levels in unstimulated PM as well as stimulated cells with LPS, Dex, LPS + Dex, zymosan and PMA, respectively. Values were derived from Fig. 6 and expressed as \% ANP mRNA content (unstimulated cells $100 \%$ ). Values are given as means \pm SD.

Dex: $11.1 \pm 2.2 \mathrm{NS}$; LPS/Dex: $20.3 \pm 2.9 \mathrm{fmol} / \mathrm{mg}$ protein, $P<0.05$ ).

Regarding the amount of secreted ANP-IR (basal: 34.2 $\pm 12.1 \mathrm{fmol} / \mathrm{mg}$ cell protein) combination of DEX/LPS appears to exert the strongest effects on ANP secretion (225.7 \pm 48.1 versus LPS: $85.5 \pm 15.4$, both $P<0.05$; DEX: $68.0 \pm 21.4 \mathrm{fmol} / \mathrm{mg}$ cell protein) (Fig. 8). Calculating the total amount of both intra- and extracellular ANP-IR it appears that DEX elicits a 1.7-fold, LPS a 2.8-fold and the combination of both substances a 5.5-fold stimulation of ANP in macrophages.

\section{Discussion}

The presented paper communicates the following major findings: First, ANP represents a common constituent of macro-

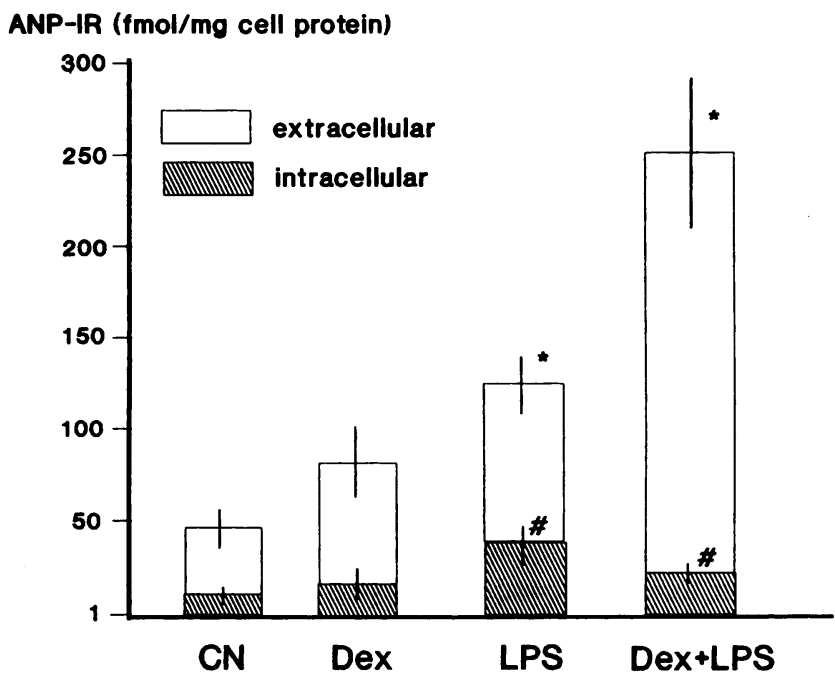

Figure 8. Effect of exposure of BMM to various substances on intracellular and secreted ANP-IR. ANP-IR has been extracted, purified and quantified as described in Methods. Cells were incubated with LPS ( 1 $\mu \mathrm{g} / \mathrm{ml}, 24 \mathrm{~h})$, Dex $\left(10^{-7} \mathrm{M}, 24 \mathrm{~h}\right)$ or a combination of both substances. ANP-IR of cells as well as of the medium is expressed as $\mathrm{fmol} / \mathrm{mg}$ protein (values corrected for recovery) and represents the mean of three independent experiments \pm SD. ${ }^{* *} P<0.05$. 
phages. This finding extents data reported for thymic macrophages $(11,12)$, as mRNA coding for ANP as well as the product (ANP99-126 IR) has now been demonstrated in PM as well as in BMM. The characterization of the cultured macrophages (purity and functional activity) has been determined by FACS analysis. Second, macrophages not only produce ANP but also secrete the peptide. The biologically active ANP99126 has been detected in the culture medium after enrichment by means of immunoaffinity chromatography. Third, ANP expression and secretion is regulated by compounds affecting macrophage functions, such as LPS, Dex, and zymosan.

Referring to the methodology used in our investigations, special attention has been payed to the quantification of PCR products by use of competitive PCR as well as by chromatographic procedures to quantify and characterize ANP-IR. By means of HPLC analysis the presence of ANP99-126 was found both intra- and extracellularly of macrophages. This conflicts with reports of thymic macrophages as in these cells the prohormone ANP1-126 represents the major form of ANP-IR (8-12). We believe, thus, that the in vitro conditions may be responsible for the distinct ANP processing. Proteases taken up from the medium (27) as well as cortisol-like material originating from fetal calf serum $\left(\sim 10^{-9} \mathrm{M}\right)$ may induce transition of ANP1126 to ANP 99-126, as the corticosteroid dexamethasone has been shown to mediate processing of ANP1-126 in myocytes (28). Data obtained from cells cultured with cortisol-reduced medium $\left(<10^{-11} \mathrm{M}\right)$ support this notion as the ANP-IR identified as ANP1-126 exceeds the low molecular weight material in these cell preparations.

Macrophages produce a variety of other peptides $(29,30)$ including $\beta$-endorphin and endothelin $(31,32)$. However, the function of these peptides largely remains to be elucidated. With respect to ANP it is of interest, that its expression is affected by immunomodulatory substances. In fact, this may provide a first hint towards its involvement in immunological functions. When we selected the immunomodulators, two aspects were in mind. First, we wanted to strengthen the hypothesis that an activation of macrophages rather than a Dex-specific effect triggers an increased production of ANP in the involuted thymus $(11,12)$. Of further interest was to examine whether an increased ANP synthesis is a general feature of activated macrophages. Therefore, cultured macrophages were exposed to Dex as well as to LPS. LPS is known to induce a highly activated status of macrophages (29), thereby increasing the phagocytic activity as well as the production and release of various cytokines and other factors $(33,34)$. Dex seems to negatively regulate macrophage functions such as release of cytokines or both their tumoricidal and microbicidal activities $(35,36)$. On the other hand, Dex is known to stimulate ANP production in other cells $(37,38)$. Second, compounds such as zymosan and PMA have been selected to consider specific mechanisms of activation of macrophages responsible for increased ANP production. Zymosan, a cell wall compound of yeast, is highly phagocytosed thereby triggering the respiratory burst (39). PMA is also able to stimulate production of oxygen radicals by phagocytes (18).

The data show that LPS represents a stronger stimulus on expression of mRNA coding for ANP as well as ANP production as observed for Dex. Therefore, a general activation of macrophages rather than a Dex-specific effect may account for the stimulated ANP status of thymic macrophages. Moreover, this finding seems to apply to macrophages in general. It should be noted, however, that a combination of LPS and Dex induces the maximal ANP production measured. LPS elevates glucocorticoid receptor expression in murine macrophages (40) which in turn brings about an increased glucocorticoid sensitivity of the cells. We propose therefore, that LPS may enhance the effect of Dex on ANP production.

The even more potent effect of zymosan on ANP expression suggests that activation of phagocytosis may represent a major mechanism for stimulated ANP production in macrophages as has been reported for other constituents of these cells (41). Increased phagocytosis also occurs in the acutely involuted thymus therefore supporting previous findings $(11,12)$. Interestingly, stimulation of respiratory burst activity seems less likely to be linked to ANP expression, as PMA failed to interfere with the peptide's synthesis.

Taken together, expression and secretion of ANP by macrophages is correlated with their activation (phagocytosis) which suggests a cytokine-like activity of ANP. Therefore, ANP originating from these immune cells may contribute to local and systemic aspects of host defense mechanism. First informations on corresponding functional activities of ANP have been reported $(42,43)$. ANP produced by macrophages may also control the vascular tone in sites of inflammation as the peptide is known to induce vasorelaxation (1).

\section{Acknowledgments}

This work is dedicated to Professor Dr. G. Paumgartner in honor of his 60th birthday.

We would like to thank Ms. U. Rüberg, C. Siegl, K. Wetzig for excellent technical assistance and Ms. Eeva Partaanen for performing the immunocytochemistry. Dr. Mona Nemer, Institute of Clinical Research, Montreal and Dr. A. L. Gerbes, Department of Medicine, Munich, are thanked for their support in performing PCR. We are grateful to Dr. F. Sinowatz, Munich, for the immunohistochemical photographs.

Work was supported by the Deutsche Forschungsgemeinschaft (Vo $376 / 6-1)$

\section{References}

1. Brenner, B. M. B. J. Ballermann, M. E. Gunnig, and M. L. Zeidel. 1990 Diverse biological actions of atrial natriuretic peptide. Physiol. Rev. 70:665-699.

2. Gutkowska, J., and M. Nemer. 1989. Structure, expression and function of atrial natriuretic factor in extraatrial tissues. Endocr. Rev. 10:519-536.

3. Vollmar, A. M. 1990. Atrial natriuretic peptide in peripheral organs other than the heart. Klin. Wochenschr. 68:699-708.

4. Pandey, K. N., S. N. Pavlou, W. J. Kovacs, and T. Inagami. 1986. Atrial natriuretic factor regulates steroidogenic responsiveness and cyclic nucleotide levels in mouse Leydig cells in vitro. Biochem. Biophys. Res. Commun. 138:399404.

5. Appel, R. G. 1990. Mechanism of atrial natriuretic factor-induced inhibition of rat mesangial cell mitogenesis. Am. J. Physiol. 259:E312-E316.

6. Pella, R. 1991. The protective effect of atrial natriuretic peptide (ANP) on cells damaged by oxygen radicals is mediated through elevated cGMP-levels, reduction of calcium-inflow and probably G-proteins. Biochem. Biophys. Res. Commun. 174:549-553.

7. Vollmar, A. M., A. Friedrich, F. Sinowatz, and R. Schulz. 1988. Presence of atrial natriuretic peptide-like material in guinea pig intestine. Peptides. 9:965971.

8. Vollmar, A. M., and R. Schulz. 1990. Presence of ANP in lymphoid organs of various species. Comp. Biochem. Physiol. 94A:459-463.

9. Vollmar, A. M., and R. Schulz. 1990. Atrial natriuretic peptide is synthesized in the human thymus. Endocrinology. 126:2277-2281.

10. Vollmar, A. M., and R. Schulz. 1990. Dexamethasone action on rat thymic atrial natriuretic peptide. Endocrinology. 127:3240-3242.

11. Vollmar, A. M., and R. Schulz. 1993. Increased production of atrial natriuretic peptide in the rat thymus after irradiation. Immunopharmacology. 26:65-72.

12. Vollmar, A. M., F. Colbatzky, and R. Schulz. 1992. Expression of atrial 
natriuretic peptide in thymic macrophages after dexamethasone treatment of rats. Cell Tissue Res. 268:397-399.

13. Trosby, M., Z. Yang, D. Lee, W. Huang, D. L. Copolov, and A. T. Lim. 1993. In vitro evidence for atrial natriuretic factor-(5-28) production by macrophages of adult rat thymi. Endocrinology. 132:2184-2190.

14. Stanley, E. R., D. M. Chen, and H. S. Lin. 1978. Induction of macrophage production and proliferation by a purified colony stimulating factor. Nature (Lond.). 274:168-170.

15. Szu-Hee, L., P. M. Starkey, and S. Gordon. 1985. Quantitative analysis of total macrophage content in adult mouse tissues. J. Exp. Med. 161:475-489.

16. Koski, I. R., D. G. Poplak, and R. M. Blaese. 1976. A nonspecific esterase stain for identification of monocytes and macrophages. In In vitro methods in cell-mediated and tumor immunity. B. R. Bloom and J. R. Davis, editors. Academic press, New York, 359-368.

17. Parod, R. J., and J. D. Brain. 1983. Uptake of latex particles by macrophages: characterization using flow cytometry. Am. J. Physiol. 245:C220-234.

18. Emmendörfer, A., M. Hecht, M. L. Lohmann-Matthes, and J. Roessler. 1990. A fast and easy method to determine the production of reactive oxygen intermediates by human and murine phagocytes using dihydrorhodamine-123. $J$. Immunol. Methods. 131:269-275.

19. Chirgwin, J. M., A. E. Przybyla, R. J. MacDonald, and W. J. Rutter. 1979. Isolation of biologically active ribonucleic acid from sources enriched in ribonuclease. Biochemistry 18:5294-5299.

20. Seidman, C. E., K. Bloch, K. Klein, J. Smith, and J. Seidman. 1984. Nucleotide sequence of the human and mouse atrial natriuretic factor genes. Science (Wash. DC). 226:1206-1209.

21. Dagnino L., J. Drouin, and M. Nemer. 1991. Differential expression of natriuretic peptide genes in cardiac and extracardiac tissues. Mol. Endocrinol. 5:1292-1300.

22. Vollmar, A. M., A. L. Gerbes, M. Nemer, and R. Schulz. 1993. Detection of C-type natriuretic peptide (CNP) transcript in the rat heart and immune organs. Endocrinology. 132:1872-1874.

23. Sambrook, J., E. F. Fritsch, and T. Maniatis. 1989. Molecular Cloning: A Laboratory Manual, second edition. Cold Spring Harbor Laboratory Press, Cold Spring Harbor, NY.

24. Gilliland, G., S. Perrin, K. Blanchard, and H. F. Bunn. 1990. Analysis of cytokine mRNA and DNA: detection and quantitation by competitive polymerase chain reaction. Proc. Natl. Acad. Sci. USA. 87:2725-2729.

25. Zamboni, L., and C. DeMartino. 1976. Buffered picric acid formaldehyde: a new rapid fixative for electron microscopy. J. Cell Biol. 35:148a (Abstr.).

26. Friedrich, A., R. Schulz, and H. H. D. Meyer. 1992. Use of enzyme immunoassay and reverse-phase-high-performance liquid chromatography to detect and confirm identity of dexamethasone in equine blood. Am. J. Vet. Res. 53:2213-2220.

27. Bloch, K. D., J. B. Zisfein, M. N. Margolies, C. F. Homcy, J. G. Seidman, and R. M. Graham. 1987. A serum protease cleaves proANF into a 14-kilodalton peptide and ANF. Am. J. Physiol. 252:E147-E151.

28. Shields, P. P., J. E. Dixon, and C. C. Glembotski. 1988. The secretion of atrial natriuretic factor-(99-126) by cultured cardiac myocytes is regulated by glucocorticoids. J. Biol. Chem. 263:12619-12625.

29. Adams, D. O., and T. A. Hamilton. 1984. The cell biology of macrophage activation. Annu. Rev. Immunol. 2:283-318.

30. Blalock, J. E. 1989. A molecular basis for bidirectional communication between the immune and neuroendocrine systems. Physiol. Rev. 69:1-32.

31. Lolait, S. J., J. A. Clemens, A. J. Markwick, C. Cheng, M. McNally, A. Smith, and J. W. Funder. 1986. Proopiomelanocortin messenger ribonucleic acid and posttranscriptional processing of beta endorphin in spleen macrophages. $J$. Clin. Invest. 77:1776-1784.

32. Ehrenreich, H., R. W. Anderson, C. H. Fox, P. Rieckmann, G. S. Travis, J. E. Coligan, J. H. Kehrl, and A. S. Fauci. 1990. Endothelins, peptides with potent vasoactive properties, are produced by human macrophages. J. Exp. Med. 171:1741-1748.

33. Cooper, P. H., P. Mayer, and M. Baggiolini. 1984. Stimulation of phagocytosis in bone marrow-derived mouse macrophages by bacterial lipopolysaccharide: correlation with biochemical and functional parameters. J. Immunol. 133:913922.

34. Dentener, M. A., V. Bazil, E. J. U. Asmuth, M. Ceska, and W. A. Burman. 1993. Involvement of CD14 in lipopolysaccharide-induced tumor-necrosis-factor$\alpha$, Il- 6 and Il-8 release by human monocytes and alveolar macrophages. J. Immunol. 150:2885-2891.

35. Snyder, D. S., and E. R. Unanue. 1982. Corticosteroids inhibit murine macrophage Ia expression and interleukin-1 production. J. Immunol. 129:18031809.

36. Hogan, M. M., and S. N. Vogel. 1988. Inhibition of macrophage tumoricidal activity by glucocorticoids. J. Immunol. 140:513-518.

37. Gardner, D. G., B. J. Gertz, C. F. Deschepper, and D. Y. Kim. 1988. Gene for the rat atrial natriuretic peptide is regulated by glucocorticoids in vitro. $J$. Clin. Invest. 82:1275-1281.

38. Huang W., C. L. Choi, Z. Yang, D. L. Copolov, and A. T. Lim. 1991. Forskolin-induced immunoreactive atrial natriuretic peptide (ANP) secretion and pro-ANP messenger ribonucleic acid expression of hypothalamic neurons in culture: modulation by glucocorticoids. Endocrinology. 128:2591-2600.

39. Green, S. P., J. A. Hamilton, and W. A. Philips. 1992. Zymosan-triggered tyrosine phosphorylation in mouse bone-marrow-derived macrophages is enhanced by respiratory-burst priming agents. Biochem. J. 288:427-432.

40. Salkowski, C. A., and S. N. Vogel. 1992. Lipopolysaccharide increases glucocorticoid receptor expression in murine macrophages - a possible mechanism for glucocorticoid-mediated suppression of endotoxicity. J. Immunol. 149:4041-4047

41. Rankin, J. A., I. Sylvester, S. Smith, T. Yoshimura, and E. J. Leonard. 1990. Macrophages cultured in vitro release leukotriene $B_{4}$ and neutrophil attractant/activation protein (interleukin 8 ) sequentially in response to stimulation with lipopolysaccharide and zymosan. J. Clin. Invest. 86:1556-1563.

42. Wiedermann, C. J., M. Niedermühlbichler, and H. Braunsteiner. 1992. Priming of polymorphonuclear neutrophils by atrial natriuretic peptide. J. Clin. Invest. 89:1580-1586.

43. Moss, R. B., and M. G. Golighty. 1991. In vitro enhancement of natural cytotoxicity by atrial natriuretic peptide fragment 4-28. Peptides. 12:851-854. 